\title{
Polyphasic, Including MALDI-TOF MS, Evaluation of Freeze-Drying Long-Term Preservation on Aspergillus (Section Nigri) Strains
}

\author{
Rodrigo Rodriguez ${ }^{1}$, Carla Santos ${ }^{1}$, Marta F. Simões ${ }^{2} \oplus$, Célia Soares ${ }^{1}$, Cledir Santos ${ }^{3, *}(\mathbb{C}$ and \\ Nelson Lima ${ }^{1}[$ \\ 1 CEB-Centre of Biological Engineering, Micoteca da Universidade do Minho, University of Minho, 4710-057 \\ Braga, Portugal \\ 2 State Key Laboratory of Lunar and Planetary Sciences, Space Science Institute. Macau University of Science \\ and Technology, Avenida Wai Long, Taipa, Macau SAR 999078, China \\ 3 Department of Chemical Sciences and Natural Resources, BIOREN-UFRO Scientific and Technological \\ Bioresource Nucleus, Universidad de La Frontera, Temuco 4811-230, Chile \\ * Correspondence: cledir.santos@ufrontera.cl; Tel.: +56-452-596-726
}

Received: 7 August 2019; Accepted: 24 August 2019; Published: 25 August 2019

\begin{abstract}
This study aims to evaluate the effect of freeze-drying and long-term storage on the biotechnological potential of Aspergillus section Nigri strains. Twelve selected strains were freeze-dried and aged by accelerated storage, at $37^{\circ} \mathrm{C}$ in the dark, for 2 and 4 weeks. To assess possible changes as a consequence of the ageing in the freeze-drying ampoules, morphological characteristics, mycotoxins and enzymes production, matrix-assisted laser desorption/ionisation time-of-flight mass spectrometry (MALTI-TOF MS) spectra, and M13 phage probe fingerprinting were used as part of a polyphasic approach. Phenotypical changes were observed; nevertheless, they did not substantially affect the potential biotechnological use of these strains. The activity of hydrolytic enzymes (protease, carboxymethylcellulase, xylanase, pectinase and mannanase) was maintained or increased after freeze-drying. MALDI-TOF MS data originated spectra that grouped, for the majority of samples, according to strain independently of preservation time point. M13 profiles revealed the presence of some genetic polymorphisms after preservation. However, the three studied times still clustered for more than $50 \%$ of strains. Our results show that the studied strains maintain their biotechnological potential after preservation, with minimal phenotypic alterations. These findings provide evidence that freeze-drying preservation is a suitable option to preserve biotechnologically relevant aspergilli strains from section Nigri, and one should consider that the observed effects might be species/strain-dependent.
\end{abstract}

Keywords: freeze-drying; accelerated ageing; mass spectrometry; DNA fingerprinting; biotechnological potential

\section{Introduction}

Environmental fungal strains can be used in (1) research, (2) diagnostic laboratories (as reference strains), (3) academic laboratories, (4) industrial biotechnology processes as well as (5) environmental biotechnology (e.g., bioremediation) [1,2]. Maintaining and preserving relevant strains is essential for research and commercial exploitation of the fungal biodiversity [3].

The Aspergilli are among the most abundant fungi on earth [4]. They can synthesise multiple metabolites, which allow them to adapt to the variety of environments they inhabit. Some of these primary and secondary metabolites have been commercially exploited; generating several Aspergillus-related products and patents including antibiotics, anti-tumoral and anti-fungal agents 
as well as other compounds with a medical application, such as the cholesterol-lowering drug lovastatin [5-9]. Additionally, Aspergilli strains are involved in many modern industrial processes including the production of hydrolytic enzymes (e.g., pectinases) [10] and bulk chemicals (e.g., citric acid) but have also been used for centuries in Asia for the production of fermented foods, such as sake, soy sauce and miso [11]. On the other hand, some Aspergillus strains are pathogens to humans and animals, being the causing agent of, e.g., aspergillomas and allergic bronchopulmonary aspergillosis in the case of $A$. fumigatus, and mycotoxicosis related with secondary metabolites produced by $A$. carbonarius, A. clavatus, A. flavus, A. niger, A. ochraceus, A. parasiticus and A. terreus [12,13]. In agriculture, A. flavus, A. parasiticus, A. niger, A. ochraceus and A. carbonarius can cause deterioration of stored crops and are opportunistic pathogens of field crops [14].

Preservation aims to find the storage conditions that minimise the number of generations from the initial isolate and decrease the metabolic activity of the cell to a minimal one [15]. Since fungi are such a diverse group, several different methods of cultivation and preservation are required to ensure that viability, and morphological, physiological and genetic characteristics of the cultures are conserved over time [16]. There are several techniques available for the preservation of filamentous fungi; nevertheless, freeze-drying is the most reliable method for long-term preservation [17]. Despite this, it is important to mention that no preservation method fits all the species and that no method guarantees total physiological and genetic stability of an isolate [1,18-20].

Recently, consistent identification and characterisation of species of filamentous fungi have been achieved employing the so-called polyphasic approach $[1,12,14,21]$. The polyphasic approach combines the use of different techniques, such as morphology, biochemical and molecular biology tools and more recently, mass spectrometry (particularly matrix-assisted laser desorption/ionisation time-of-flight mass spectrometry (MALDI-TOF MS). Furthermore, mass spectrometry based microbial spectral analysis has been used as a key step in the polyphasic identification of filamentous fungi from different fields [12,14,22-28].

The time of storage after preservation at which a given percentage of the original population remains viable and unchanged is called shelf-life. Therefore, it is desirable to know for how long the cells will remain viable and how viability will be influenced by the different preservation methods. Because of the difficulty in testing the effects of long-term storage on microbial viability, storage based on accelerated conditions that mimic the effect of long-term preservation has been previously used to promote the process of cell ageing $[29,30]$. It has been shown that accelerated storage of liquid-dried bacterial cultures for 2 weeks at $37^{\circ} \mathrm{C}$ can simulate 20 years of storage at $5{ }^{\circ} \mathrm{C}$ [29]. The process of accelerated storage has shown to be a useful tool to evaluate the efficiency of different preservation methods as well as to predict the behaviour of preserved microbiological cells after long-term storage $[29,30]$.

Although several studies have evaluated the use of different methods of preservation on Aspergillus strains viability [19,31-35], to our knowledge, none have assessed possible effects on a wide range of phenotypical characteristics after preservation in this genus. The biotechnological relevant species-Aspergillus niger-was also included in this selection as a model organism since it has been used as a cell factory for the production of a wide range of metabolites, such as organic acids, antibiotics, extracellular enzymes, as well as native and recombinant proteins. The present work aimed to apply a polyphasic approach (morphology, molecular markers, mycotoxins, enzyme secretion and MALDI-TOF MS spectral profiling) to characterise the effects of freeze-drying and accelerated storage on the biotechnological potential of 12 strains belonging to different species within Aspergillus section Nigri. 


\section{Materials and Methods}

\subsection{Fungal Strains}

Twelve strains belonging to Aspergillus section Nigri were selected and supplied by the Filamentous Fungal Culture Collection Micoteca da Universidade do Minho (MUM, Braga, Portugal) (Table 1). All samples were initially grown in malt extract agar (MEA, malt extract $20 \mathrm{~g} / \mathrm{L}$, mycological peptone $1 \mathrm{~g} / \mathrm{L}$, glucose $20 \mathrm{~g} / \mathrm{L}$, agar $20 \mathrm{~g} / \mathrm{L}$ ) and incubated in the dark at $25^{\circ} \mathrm{C}$ for 7 days, for further analyses.

Table 1. Selected Aspergillus section Nigri strains and their associated information.

\begin{tabular}{|c|c|c|c|}
\hline Species & Strain MUM No. & $\begin{array}{c}\text { Geographical } \\
\text { Origin }\end{array}$ & Substrate \\
\hline A. aculeatus & $\begin{array}{c}03.11^{\mathrm{T}} \\
\left(\mathrm{NRRL} 5095^{\mathrm{T}}\right) \text { * }\end{array}$ & Unknown & Tropical Soil \\
\hline A. brasiliensis & 06.179 & Portugal & $\begin{array}{c}\text { Grapes Cabernet } \\
\text { Sauvignon }\end{array}$ \\
\hline A. ibericus & $\begin{array}{l}03.49 \\
04.68 \\
04.86\end{array}$ & $\begin{array}{l}\text { Portugal } \\
\text { Portugal } \\
\text { Portugal }\end{array}$ & $\begin{array}{c}\text { Grapes Periquita } \\
\text { Grapes Aragonês } \\
\text { Grapes Tinta Barroca }\end{array}$ \\
\hline A. japonicus & $\begin{array}{c}98.03 \\
(\mathrm{DSM} 2345)^{* *}\end{array}$ & Unknown & Unknown \\
\hline A. lacticoffeatus & $\begin{array}{c}06.150^{\mathrm{T}} \\
\left(\text { CBS } 101883^{\mathrm{T}}\right)^{* * *}\end{array}$ & Indonesia & $\begin{array}{l}\text { Coffee Robusta } \\
\text { (Rubiaceae) }\end{array}$ \\
\hline A. niger & $\begin{array}{l}05.11 \\
05.13\end{array}$ & $\begin{array}{l}\text { Portugal } \\
\text { Portugal }\end{array}$ & $\begin{array}{l}\text { Grapes Periquita } \\
\text { Grapes Aragonês }\end{array}$ \\
\hline A. phoenicis & $\begin{array}{c}03.05 \\
(\text { NRRL 365) * }\end{array}$ & Unknown & Unknown \\
\hline A. uvarum & 08.01 & Portugal & Grapes Tinta Barroca \\
\hline A. vadensis & $\begin{array}{c}06.153^{\mathrm{T}} \\
\left(\mathrm{CBS} 113365^{\mathrm{T}}\right)^{* * *}\end{array}$ & Unknown & Dead plant tissue \\
\hline
\end{tabular}

$\mathrm{T}=\overline{\text { ex-Type strain; * Northern Regional Research Laboratory (NRRL, Beltsville, Maryland, USA); }{ }^{* *} \text { Deutsche }}$ Sammlung von Mikroorganismen und Zellkulturen-DSMZ (Braunschweig, Germany); ${ }^{* * *}$ Westerdijk Fungal Biodiversity Institute-CBS (Utrecht, The Netherlands).

\subsection{Macro and Micro-Morphological Evaluation}

For macro-morphological analysis, the selected strains were grown on: MEA, potato dextrose agar (PDA, potato infusion $200 \mathrm{~g} / \mathrm{L}$, dextrose $20 \mathrm{~g} / \mathrm{L}$, agar $15 \mathrm{~g} / \mathrm{L}$ ), Czapek agar (CZ, sucrose $30 \mathrm{~g} / \mathrm{L}$, $\mathrm{K}_{2} \mathrm{HPO}_{4} 1 \mathrm{~g} / \mathrm{L}, \mathrm{KCl} 0.5 \mathrm{~g} / \mathrm{L}, \mathrm{NaNO}_{3} 2 \mathrm{~g} / \mathrm{L}, \mathrm{MgSO}_{4} 0.5 \mathrm{~g} / \mathrm{L}, \mathrm{FeSO}_{4} 0.01 \mathrm{~g} / \mathrm{L}$, agar $15 \mathrm{~g} / \mathrm{L}$ ) and Czapek agar with yeast extract (CYA, sucrose $30 \mathrm{~g} / \mathrm{L}$, yeast extract $5 \mathrm{~g} / \mathrm{L}, \mathrm{K}_{2} \mathrm{HPO}_{4} 1 \mathrm{~g} / \mathrm{L}, \mathrm{NaNO}_{3} 0.3 \mathrm{~g} / \mathrm{L}, \mathrm{KCl}$ $0.05 \mathrm{~g} / \mathrm{L}, \mathrm{MgSO}_{4} 0.05 \mathrm{~g} / \mathrm{L}, \mathrm{FeSO}_{4} 0.001 \mathrm{~g} / \mathrm{L}, \mathrm{ZnSO}_{4} 0.001 \mathrm{~g} / \mathrm{L}, \mathrm{CuSO}_{4} 0.0005 \mathrm{~g} / \mathrm{L}$, agar $\left.15 \mathrm{~g} / \mathrm{L}\right)$. Each plate was inoculated at 3 equidistant points and incubated in the dark, at $25^{\circ} \mathrm{C}$ for 7 days.

For microscopic and stereomicroscopic analyses, the strains were grown for 3 or 4 days on MEA. To have a clear image comparison of the size of the conidial head, a Leica MZ12.5 stereomicroscope (Leica Microsystems $\mathrm{GmbH}$, Wetzlar, Germany) was used. The fungal characterisation was carried out using a Leica DM R light microscope (Leica Microsystems GmbH, Wetzlar, Germany). Samples were mounted on a slide, abundantly washed with ethanol (96\%) to remove excessive spores and stained with a lactophenol blue solution.

\subsection{Proteolytic Activity Determination}

This assay was done by evaluating the activity of proteases through substrate degradation, observed by the appearance of a transparent column beneath the fungal colony. Skim milk agar 
medium (SKM, glucose $10 \mathrm{~g} / \mathrm{L}, \mathrm{KH}_{2} \mathrm{PO}_{4} 1 \mathrm{~g} / \mathrm{L}, \mathrm{KCl} 0.5 \mathrm{~g} / \mathrm{L}, \mathrm{MgSO}_{4} .7 \mathrm{H}_{2} \mathrm{O} 0.2 \mathrm{~g} / \mathrm{L}, \mathrm{CaCl}_{2} \cdot 7 \mathrm{H}_{2} \mathrm{O} 0.1 \mathrm{~g} / \mathrm{L}$, skim milk $22.5 \%$ (w/v) $25 \mathrm{~mL} / \mathrm{L}$, agar $12 \mathrm{~g} / \mathrm{L}$ ) was prepared, sterilised by autoclavation at $110^{\circ} \mathrm{C}$ for $15 \mathrm{~min}$ and distributed into Falcon tubes ( $5 \mathrm{~mL}$ per tube), leaving a flat surface on the medium. The tubes were inoculated on the top with a $12 \mathrm{~mm}$ disc with all the 12 selected strains at the 3 different time points (I, II and III), and were incubated at $25^{\circ} \mathrm{C}$ in the dark for 7 days. The deep-clearing distance was measured in millimetres from the inoculated disc on the 7th day.

\subsection{Polysaccharide-Hydrolytic Activity Determination}

The enzymatic activity was assessed by screening the activity of a set of polysaccharide-degrading enzymes, which was performed according to the protocols used for high throughput screening of enzymes used at the Culture Collection CIRM-CF (International Centre of Microbial Resources dedicated to Filamentous Fungi) from the French National Institute for Agricultural Research (INRA, Marseille, France) [36].

The selected strains of Aspergillus used in this study were initially grown in MEA and incubated for 7 days at $25{ }^{\circ} \mathrm{C}$ in the dark. Spores from 7 day-old cultures were scraped with a sterile scraper and recovered into sterile $50 \mathrm{~mL}$ Falcon tubes using sterile $\mathrm{NaCl} 8.5 \mathrm{~g} / \mathrm{L}$ solution containing Tween $80(0.02 \%)$. The fungal cultures were grown in $250 \mathrm{~mL}$-baffled flasks containing $100 \mathrm{~mL}$ of malt extract-glucose-yeast extract-peptone (MGYP, malt extract $3 \mathrm{~g} / \mathrm{L}$, glucose $10 \mathrm{~g} / \mathrm{L}$, yeast extract $3 \mathrm{~g} / \mathrm{L}$, peptone $5 \mathrm{~g} / \mathrm{L}$ ). The cultures were inoculated with $2 \times 10^{5}$ spores $/ \mathrm{mL}$ and incubated at $25^{\circ} \mathrm{C}$ in duplicate under shaking at $150 \mathrm{rpm}$ with a Certomat rotary shaker for 7 days.

Aliquots of $2 \mathrm{~mL}$ from each $100 \mathrm{~mL}$ culture were taken at different days of incubation $(1,2,3,5$ and 7 days), and filtered with $0.45 \mu \mathrm{m}$ polyethersulfone membrane (Vivaspin ${ }^{\circledR}$ Sartorius, Aubagne, France). All the tubes containing the filtered culture media (enzymatic extracts) were kept at $-20^{\circ} \mathrm{C}$ until the analyses.

Polysaccharide-degrading enzyme miniaturised assays were performed using complex substrates on 96-well plates, as previously described [36]. To measure carboxymethylcellulase (CMCase), xylanase, pectinase and mannanase activities, complex substrates used in this study were carboxymethylcellulose (CMC), wheat xylan (WX), pectin of Citrus sp. (PC) and galactomannan (Man), respectively. Solutions $(1 \% \mathrm{w} / \mathrm{v})$ were prepared in sodium acetate buffer $50 \mathrm{mM}$ at $\mathrm{pH}=5.2$. In microtubes, $25 \mu \mathrm{L}$ of enzymatic extract was added to $150 \mu \mathrm{L}$ of each substrate ( $200 \mu \mathrm{L}$ of final volume per microtube). Afterwards, all microtubes were incubated at $37^{\circ} \mathrm{C}$ for $2 \mathrm{~h}$. Reducing sugars were quantified using the adapted dinitrosalicylic acid (DNS) method described by [37]. The enzyme activities were expressed as nanokatal/millilitre, defined as $1 \mathrm{nmol}$ glucose equivalent released per millilitre of medium and per second under the assay conditions. Glucose was used to determine a standard curve. In addition, and for control, the total protein was determined by the Bradford method using bovine serum albumin as standard [38]. A miniaturised assay was performed on a 96-well plate, with a final volume of $200 \mu \mathrm{L}$, using $40 \mu \mathrm{L}$ of reagent and $160 \mu \mathrm{L}$ of the sample. After homogenisation, the absorbance was measured at $595 \mathrm{~nm}$.

\subsection{Assessment of Mycotoxins Production}

For ochratoxin A (OTA) production, all Aspergillus strains were tested in yeast extract sucrose (YES, yeast extract $20 \mathrm{~g} / \mathrm{L}$, sucrose $150 \mathrm{~g} / \mathrm{L}, \mathrm{MgSO}_{4} 0.5 \mathrm{~g} / \mathrm{L}$, agar $20 \mathrm{~g} / \mathrm{L}$ ), at the different time points (I, II and III). The strains were inoculated on $90 \mathrm{~mm}$ diameter Petri dishes and incubated at $25^{\circ} \mathrm{C}$ for 7 days in the dark. The extraction methodology described in [39] was employed. Briefly, 3 agar plugs were removed from one colony and placed into a $4 \mathrm{~mL}$ vial, where $1 \mathrm{~mL}$ of methanol was added. After $60 \mathrm{~min}$, the extract was filtered through $25 \mathrm{~mm}$ syringe filters with $0.45 \mu \mathrm{m}$ PTFE membranes (VWR International) into new $2 \mathrm{~mL}$ vials, evaporated and further dissolved in $1 \mathrm{~mL}$ of a solution composed of water:acetonitrile:acetic acid $(99: 99: 2 \mathrm{v} / \mathrm{v} / \mathrm{v})$.

Samples were analysed by HPLC with a Jasco (Tokyo, Japan) FP-920 fluorescence detector (333 nm excitation wavelength; $460 \mathrm{~nm}$ emission wavelength). Chromatographic separations were performed 
on a reverse phase C18 column YMC-Pack ODS-AQ $(250 \times 4.6 \mathrm{~mm}, 5 \mu \mathrm{m}$; YMC Europa GmbH, Dinslaken, Germany) fitted with a pre-column with the same stationary phase. The mobile phase was water:acetonitrile:acetic acid $(99: 99: 2, \mathrm{v} / \mathrm{v})$ pumped at $0.8 \mathrm{~mL} / \mathrm{min}$. The injection volume was $50 \mu \mathrm{L}$. OTA standard was supplied by Biopure (Getzersdorf, Austria). An initial calibration curve was prepared, and quantification was made using Galaxie software (1.9.302.952 version) and extracts, with the same retention time as OTA standard, were considered to be OTA positive. The limits of detection (LOD) and quantification (LOQ) were $0.72 \mathrm{ng} / \mathrm{mL}$ and $3.29 \mathrm{ng} / \mathrm{mL}$, respectively.

Strains were also tested for the fumonisin B2 (FUM B2) mycotoxin, as previously described [40]. Briefly, strains were inoculated on CYA in $90 \mathrm{~mm}$ diameter Petri plates and incubated at $25^{\circ} \mathrm{C}$ for 7 days in the dark. For the extraction and derivatisation methodology, 5 agar plugs from one colony were placed into a $4 \mathrm{~mL}$ borosilicate amber vial, where $1 \mathrm{~mL}$ of methanol:water (75:25, v/v) was added. After sonication for $50 \mathrm{~min}$, the extract was filtered through $25 \mathrm{~mm}$ syringe filters with $0.45 \mu \mathrm{m}$ PTFE membranes (VWR International), evaporated, kept at $4{ }^{\circ} \mathrm{C}$ until further derivatisation for FUM B2 detection [40].

Samples were analysed by HPLC with a Jasco FP-920 fluorescence detector (420 nm excitation wavelength; $500 \mathrm{~nm}$ emission wavelength). Chromatographic separations were performed on a reverse phase C18 column YMC-Pack ODS-AQ $(250 \times 4.6 \mathrm{~mm}, 5 \mu \mathrm{m})$, fitted with a precolumn with the same stationary phase. The mobile phase was acetonitrile:water:acetic acid $(60: 40: 1, \mathrm{v} / \mathrm{v} / \mathrm{v})$ pumped at $1.0 \mathrm{~mL} / \mathrm{min}$. The injection volume was $50 \mu \mathrm{L}$. FUM B2 standard was supplied by Sigma-Aldrich (St. Louis, MO, USA). An initial calibration curve was prepared, and quantification was made using Galaxie software (1.9.302.952 version) and extracts with the same retention time as FUM B2 standard were considered to be FUM B2 positive. The LOD and LOQ were $75 \mathrm{ng} / \mathrm{mL}$ and $301.4 \mathrm{ng} / \mathrm{mL}$, respectively.

\subsection{MALDI-TOF MS: Proteome Fingerprinting}

Samples at the different timing of preservation (I, II and II) were grown on MEA, incubated in the dark at $25^{\circ} \mathrm{C}$ for 4 days and used for spectral analysis by Matrix-Assisted Laser DesorptionMonisation Time-Of-Flight Mass Spectrometry (MALDI-TOF MS) in the range from 2 to $20 \mathrm{kDa}$. The procedures were followed as described in [23]. Briefly, for the flex target plate preparation, approximately $1 \mu \mathrm{g}$ of spores and young mycelium of each species was transferred directly from the culture plate to the MALDI-TOF sample plate. Immediately after, $0.5 \mu \mathrm{L}$ of matrix solution $(7.5 \% 2,5$-dihydroxybenzoic acid in ethanol/water/acetonitrile (1:1:1) with $0.03 \%$ trifluoroacetic acid) was added to the samples and mixed gently. The sample mixtures were air-dried at room temperature. Each sample was processed in duplicate to test reproducibility. During the analyses, all solutions were prepared and stored at $4{ }^{\circ} \mathrm{C}$.

\subsection{Molecular Biology: Typing Assays}

Genomic DNA was extracted using a modified protocol described in [12]. Briefly, spores of each strain were transferred from a 7 days old culture into $50 \mathrm{~mL}$ Falcon tubes containing $25 \mathrm{~mL}$ of MGYP. Samples were incubated at room temperature for 5 days in the dark, at $150 \mathrm{rpm}$ in a shaker. Fungal biomasses were filtrated and stored at $-20^{\circ} \mathrm{C}$.

For DNA extraction, $100 \mathrm{mg}$ of biomasses were transferred into a $1.5 \mathrm{~mL}$ Eppendorf tube containing $100 \mu \mathrm{L}$ of lysis buffer (200 mM Tris-HCl pH 8.5, $250 \mathrm{mM} \mathrm{NaCl}, 25 \mathrm{mM}$ EDTA, 0.5\% (w/v) SDS). Cell lysis was performed using a pellet pestle for 3 to $4 \mathrm{~min}$. After mechanical lysis, $900 \mu \mathrm{L}$ of lysis buffer was added, and the samples were incubated for $1 \mathrm{~h}$ at $65^{\circ} \mathrm{C}$. Samples were centrifuged at $14,000 \times g$ for $10 \mathrm{~min}$ at room temperature, and $800 \mu \mathrm{L}$ of the upper phase was transferred into a new $2 \mathrm{~mL}$ Eppendorf tube. Polysaccharides and proteins were precipitated by adding $1 \mathrm{~mL}$ of cold sodium acetate ( $3 \mathrm{M}$, $\mathrm{pH}$ 5.5).

Samples were gently mixed by inversion, placed at $-20^{\circ} \mathrm{C}$ for $10 \mathrm{~min}$ and centrifuged at $14,000 \times g$ for $10 \mathrm{~min}$ at room temperature. Clean supernatant was then transferred to a new tube and precipitated with one volume of cold isopropanol $\left(-20^{\circ} \mathrm{C}\right)$. Samples were gently mixed by inversion for $2 \mathrm{~min}$, incubated at $-20^{\circ} \mathrm{C}$ for $2 \mathrm{~h}$ and centrifuged at $14,000 \times \mathrm{g}$ for $10 \mathrm{~min}$. DNA pellets were washed twice 
with $1.0 \mathrm{~mL}$ of cold $70 \%$ ethanol, centrifuged at $14,000 \times \mathrm{g}$ for $10 \mathrm{~min}$ and dried using a SpeedVac Concentrator. DNA samples were suspended on $50 \mu \mathrm{L}$ of ultra-pure water, treated with $10 \mathrm{mg}$ of RNase A for $1 \mathrm{~h}$ at $37^{\circ} \mathrm{C}$ and stored at $-20^{\circ} \mathrm{C}$. Samples were subjected to quality assessment by quantification of total DNA using the Qubit dsDNA HS Assay Kit with the Qubit ${ }^{\circledR} 2.0$ Fluorometer (Invitrogen; Thermo Fisher Scientific, Inc., Waltham, MA, USA), and by electrophoresis on 1\% (w/v) agarose gels in Tris-acetate-EDTA (TAE) buffer.

DNA fingerprinting was performed using the M13 phage probe 5'-GAGGGTGGCGGTTCT-3' [41]. M13 PCR reactions used 1x VWR Taq DNA Polymerase Master Mix with $1 \mathrm{mM} \mathrm{MgCl} 2,0.8 \mu \mathrm{M}$ primer M13 and $50 \mathrm{ng}$ of genomic DNA in a $25 \mu \mathrm{L}$ reaction volume. Thermal cycling parameters were $94{ }^{\circ} \mathrm{C}$ for $2 \mathrm{~min}, 40$ cycles of $94{ }^{\circ} \mathrm{C}$ for $20 \mathrm{~s}, 50^{\circ} \mathrm{C}$ for $1 \mathrm{~min}, 72{ }^{\circ} \mathrm{C}$ for $20 \mathrm{~s}$ and a final extension at $72{ }^{\circ} \mathrm{C}$ for $6 \mathrm{~min}$. Products were separated by electrophoresis on $1.5 \%(\mathrm{w} / \mathrm{v})$ agarose gels in TAE buffer.

\subsection{Data Analysis}

For proteome fingerprinting, the data were analysed based on a matrix of pairwise correlation values for spectra after smoothing baseline corrections and peak detections. The peak lists of the selected strains were directly exported to the SARAMISTM software package (Spectral Archiving and Microbial Identification System, AnagnosTec, Version 2010, Potsdam, Germany, 2010). A dendrogram of proteomic profile proximity among isolates was created using SARAMISTM package.

For M13 fingerprinting analysis, BioNumerics 7.6 software (Applied Maths NV, Sint-Martens-Latem, Belgium) was used to calculate pairwise similarity values based on the Dice coefficient and converted into a dendrogram by unweighted pair group method with arithmetic means (UPGMA). The cophenetic correlation coefficient was determined, and the values associated with the branches were figured out on the nodes. Additionally, principal component analysis (PCA) was performed to show the relationships among samples.

The experimental design did not involve replication of the experiments, and as a matter of consequence, statistical analysis was not performed. The exception was the work developed for M13 typing assay that was performed in two independent assays. However, the results were similar and only one set of the results are presented.

\section{Results and Discussion}

\subsection{Viability, Growth and Morphological Analyses}

All the twelve selected Aspergillus strains were able to grow on a variety of fungal media after freeze-drying and accelerated storage conditions $\left(37^{\circ} \mathrm{C}\right.$ in the dark for 2 and 4 weeks) including MEA, PDA, CZ and CYA. All tested strains successfully survived preservation conditions equivalent to 40 -years of storage at $5{ }^{\circ} \mathrm{C}$.

Figure 1 is a representative image for both the macro-morphological and the micro-morphological characteristics, showing fungal colony general colour and its morphological characteristics, and conidiophores at the three different ageing times under light microscopy. Macro-morphology of the colonies (conidial colour and mycelial colour) showed no substantial differences in the recovered cultures grown in different media and after freeze-drying (Figure 1). In contrast, sectorisation representing phenotypical degeneration was observed in approximately $30 \%$ of the inoculated plates. A. aculetaus MUM 03.11 (Figure 2) with A. ibericus MUM 04.86 were the most sectorised strains observed. When comparing the different preservation time points, we have observed an increased number of sectorised strains for all studied media from points I (9\%) and II (9\%) to point III (13\%) (Table 2). Previous studies have linked this phenomenon to gene expression disruption, unstable mtDNA and mitochondrial dysfunctions, and oxidative stress, having a possible impact in the strains' capacity to produce secondary metabolites and enzymes [42-45]. Conidiophores and spores maintained their morphological structure and did not present any changes during and after ageing. Mycelial extension rates of all strains were nearly unaffected by the freeze-drying process, but it was possible to observe a 
stimulation of conidiophore production and sporulation, particularly in CZ and CYA. No differences in micro-morphological characteristics (presence or absence of clamp connections, presence or absence of hyphal vacuolisation and shape and branching of hyphae) were observed between strains before and after preservation (data not shown). Aspergillus aculeatus, A. japonicus and A. uvarum were the only uniseriate species presenting only phialides whilst all the other strains presented metulae and phialides (biseriate). These micro-morphological observations are totally aligned with previous taxonomic reports for Section Nigri $[46,47]$. Moreover, each species presented spores with different characteristics, either in shape, size and ornamentation features. These features were common and equal for all the time points analysed.

TI

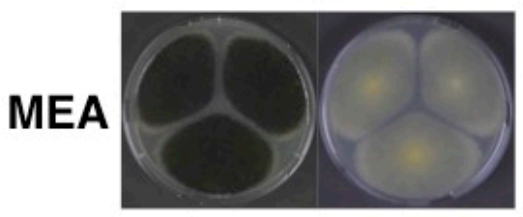

PDA

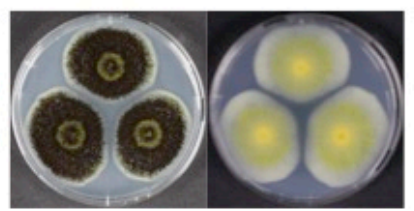

CZ

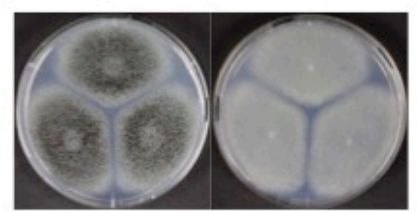

CYA

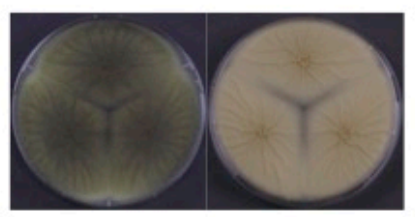

SMic

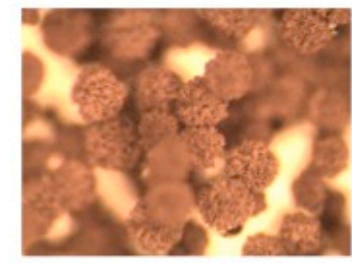

LMic

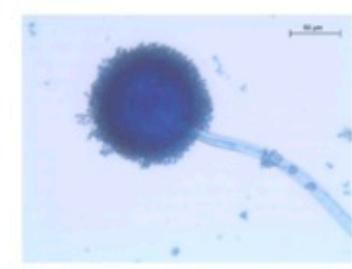

TII
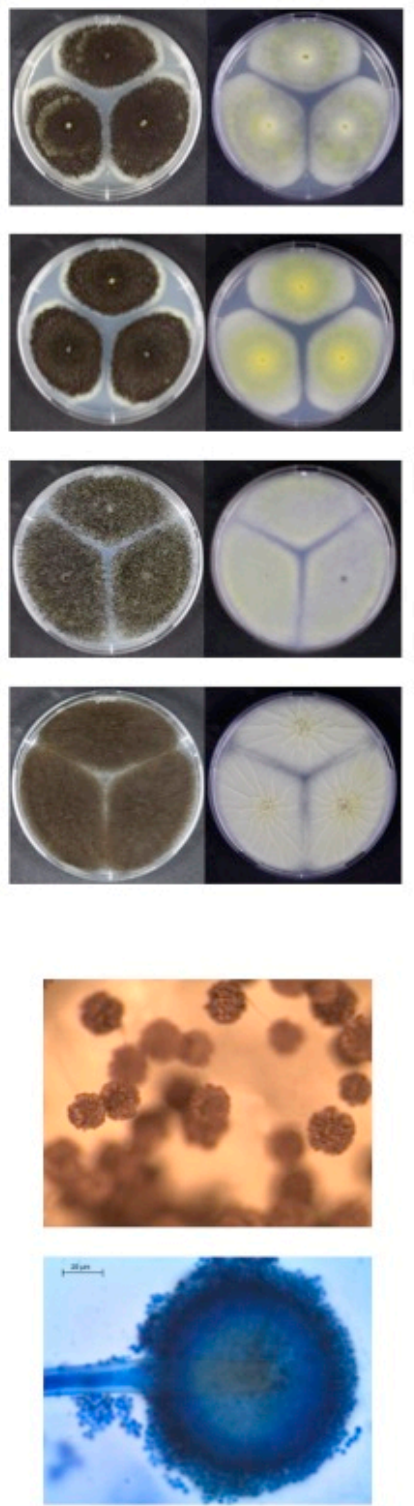

TIII
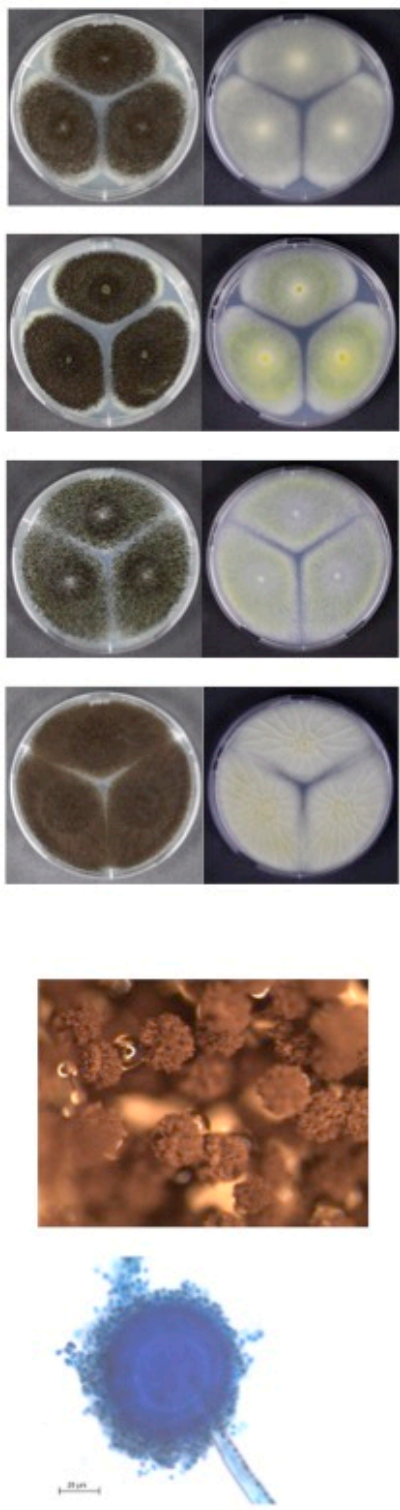

Figure 1. Morphological characteristics of Aspergillus niger Filamentous Fungal Culture Collection Micoteca da Universidade do Minho (MUM) 05.11 before (TI), after 2 weeks (TII) and 4 weeks (TIII) of freeze-drying and accelerated storage. Obverse (left) and reverse (right) of colonies grown for 7 days in the dark, at $25^{\circ} \mathrm{C}$ on malt extract agar (MEA), potato dextrose agar (PDA), Czapek agar (CZ) and Czapek agar with yeast extract (CYA) media are shown. Stereomicroscope images (SMic) showing general colour and morphological characteristics of colony and light microscopy images (LMic) of conidiophores at the three different ageing times are also presented. 
TI

MEA

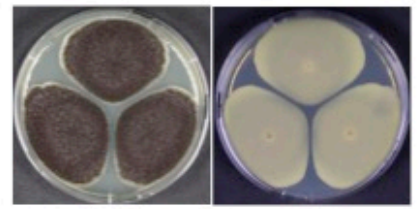

PDA

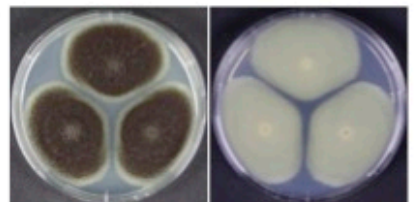

CZ

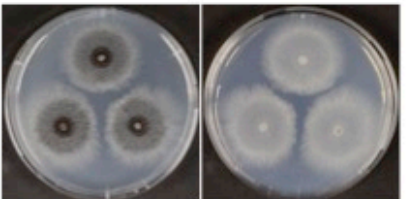

CYA

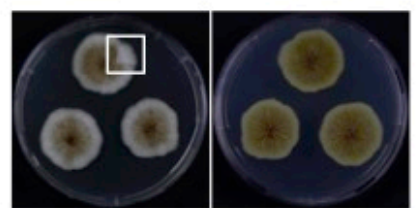

TII
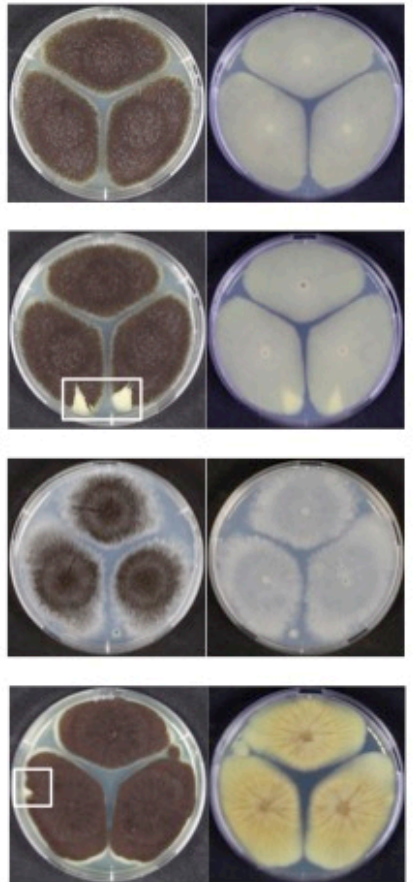

TIII
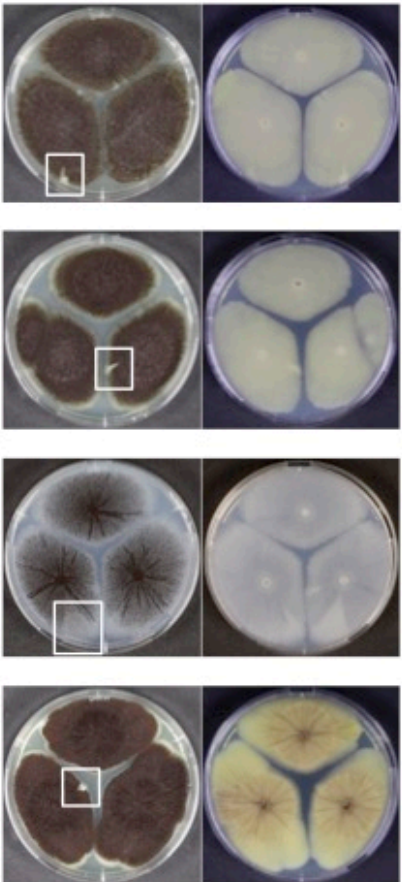

Figure 2. Morphological characteristics of Aspergillus aculeatus MUM 03.11 before (Time I), after 2 weeks (Time II) and 4 weeks (Time III) of freeze-drying and accelerated storage. Obverse (left) and reverse (right) of colonies grown for 7 days in the dark, at $25^{\circ} \mathrm{C}$ on MEA, PDA, CZ and CYA media. Sectorisation areas are indicated by white boxes.

Table 2. Percentage of phenotypical sectorisation observed of Aspergillus strains grown in four different media after 7 days in the dark, at $25^{\circ} \mathrm{C}$, for different preservation time points (before (Time I), after 2 weeks (Time II) and 4 weeks (Time III) of freeze-drying).

\begin{tabular}{ccccc}
\hline \multirow{2}{*}{ Species } & \multirow{2}{*}{ Strain MUM No. } & \multicolumn{3}{c}{ Phenotypical Sectorisation (\%) } \\
\cline { 3 - 5 } & & I & II & III \\
\hline A. aculeatus & 03.11 & 25 & 50 & 100 \\
\hline A. brasiliensis & 06.179 & 25 & nill & nill \\
\hline \multirow{2}{*}{ A. ibericus } & 03.49 & 50 & nill & 50 \\
& 04.68 & nill & 50 & 25 \\
\hline A. japonicus & 04.86 & 50 & 50 & 75 \\
\hline A. lacticoffeatus & 98.03 & 25 & 50 & 75 \\
\hline A. niger & 06.150 & 50 & 50 & 50 \\
\hline A. phoenicis & 05.11 & nill & nill & nill \\
\hline A. uvarum & 05.13 & nill & nill & nill \\
\hline A. vadensis & 03.05 & 25 & nill & nill \\
\hline
\end{tabular}

\subsection{Biochemical Characterisation: Enzymes and Mycotoxins Production}

Enzyme production is a fungal characteristic, and enzymatic activity can be analysed as part of any biotechnological potential assessment. To determine the effect of preservation and accelerated storage on the capacity of Aspergillus strains to secrete commercially relevant enzymes, all the 12 selected Aspergillus strains from the three preservation time points were grown for 7 days either on skim milk 
agar to analyse proteolytic enzymes activity on day 7 by deep-clearing measurement (Table 3) or on maltose medium and the culture media supernatant from each day was analysed for the production of the polysaccharide-hydrolytic enzymes CMCase, xylanase, pectinase and mannanase at the time points I, II and III (Table 4).

Table 3. Proteolytic activity at day 7 of Aspergillus strains different preservation time points (before (Time I), after 2 weeks (Time II) and 4 weeks (Time III) of freeze-drying).

\begin{tabular}{ccccc}
\hline \multirow{2}{*}{ Species } & Strain MUM No. & \multicolumn{3}{c}{ Deep-Clearing Distance (mm) } \\
\cline { 3 - 5 } & & I & II & III \\
\hline A. aculeatus & 03.11 & $<6$ & 11 & 11 \\
\hline A. brasiliensis & 06.179 & 11 & 11 & 9 \\
\hline \multirow{2}{*}{ A. ibericus } & 03.49 & $<6$ & 16 & 16 \\
& 04.68 & 15 & 16 & 14 \\
\hline A. japonicus & 04.86 & $<6$ & 11 & 14 \\
\hline A. lacticoffeatus & 98.03 & 8 & 6 & 7 \\
\hline A. niger & 06.150 & $<6$ & 14 & 14 \\
\hline A. phoenicis & 05.11 & $<6$ & 11 & 11 \\
\hline A. uvarum & 05.13 & $<6$ & 11 & 11 \\
\hline A. vadensis & 03.05 & 8 & 6 & 11 \\
\hline
\end{tabular}

Table 4. Maximum polysaccharide-enzymatic activity detected during 7 days for supernatants of Aspergillus strains grown in maltose broth medium at different preservation time points (before (Time I), after 2 weeks (Time II) and 4 weeks (Time III) of freeze-drying).

\begin{tabular}{|c|c|c|c|c|c|c|c|c|c|c|c|c|c|}
\hline \multirow{3}{*}{ Species } & \multirow{3}{*}{$\begin{array}{c}\text { Strain MUM } \\
\text { No. }\end{array}$} & \multicolumn{12}{|c|}{ Maximum activity (nkat/mL) } \\
\hline & & \multicolumn{3}{|c|}{ CMCase } & \multicolumn{3}{|c|}{ Xylanase } & \multicolumn{3}{|c|}{ Pectinase } & \multicolumn{3}{|c|}{ Mannanase } \\
\hline & & I & II & III & $\mathbf{I}$ & II & III & $\mathbf{I}$ & II & III & $\mathbf{I}$ & II & III \\
\hline A. aculeatus & 03.11 & 0.018 & 0.018 & 0.017 & 0.011 & 0.028 & 0.010 & 0.056 & 0.055 & 0.040 & 0.031 & 0.031 & 0.044 \\
\hline A. brasiliensis & 06.179 & 0.018 & 0.018 & 0.018 & 0.015 & 0.026 & 0.017 & 0.038 & 0.086 & 0.070 & 0.044 & 0.044 & 0.043 \\
\hline \multirow[t]{3}{*}{ A. ibericus } & 03.49 & 0.024 & 0.017 & 0.016 & 0.012 & 0.014 & 0.011 & 0.042 & 0.088 & 0.038 & 0.042 & 0.041 & 0.042 \\
\hline & 04.68 & 0.018 & 0.006 & 0.019 & 0.013 & 0.006 & 0.003 & 0.042 & 0.137 & 0.044 & 0.032 & 0.017 & 0.034 \\
\hline & 04.86 & 0.020 & 0.021 & 0.021 & 0.037 & 0.035 & 0.012 & 0.036 & 0.080 & 0.039 & 0.033 & 0.034 & 0.050 \\
\hline A. japonicus & 98.03 & 0.016 & 0.024 & 0.019 & 0.006 & 0.012 & 0.026 & 0.048 & 0.046 & 0.093 & 0.038 & 0.046 & 0.045 \\
\hline A. lacticoffeatus & 06.150 & - & - & 0.006 & - & - & 0.012 & 0.016 & 0.015 & 0.109 & $0 . .26$ & - & 0.029 \\
\hline \multirow[t]{2}{*}{ A. niger } & 05.11 & 0.017 & 0.016 & 0.020 & 0.014 & 0.009 & 0.014 & 0.026 & 0.096 & 0.058 & 0.043 & 0.041 & 0.044 \\
\hline & 05.13 & - & 0.012 & 0.019 & 0.008 & 0.007 & 0.017 & 0.026 & 0.109 & 0.037 & 0.016 & 0.038 & 0.043 \\
\hline A. phoenicis & 03.05 & 0.018 & 0.024 & 0.021 & 0.020 & 0.015 & 0.019 & 0.046 & 0.041 & 0.036 & 0.032 & 0.034 & 0.034 \\
\hline A. uvarum & 08.01 & - & 0.018 & 0.022 & - & 0.01 & 0.025 & 0.026 & 0.038 & 0.119 & 0.023 & 0.046 & 0.046 \\
\hline A. vadensis & 06.153 & 0.014 & 0.013 & 0.022 & 0.008 & 0.007 & 0.023 & 0.036 & 0.059 & 0.074 & 0.039 & 0.038 & 0.056 \\
\hline
\end{tabular}

Enzymes analysed in this screening were present in all of the Aspergillus strains tested. For all the analysed samples, it was possible to observe that those with more time of accelerated storage presented higher enzymatic activity values, especially when compared with non-aged samples (time point I). Nevertheless, no consistent pattern was observed in the increase of the enzymatic activities.

In addition to its economical relevance, Aspergillus section Nigri strains represent one of the most important sources of mycotoxins contamination of food and feed [48]. The main mycotoxins produced by this group of filamentous fungi are ochratoxin A (OTA) and fumonisins (FUMs) of the B series, in particular, FUM B2 [49-52]. 
For the assessment of OTA and FUM B2, two different concentrations of a standard solution were used as control while injecting mycotoxin samples into the HPLC. No detectable production of FUM B2 was observed for any of the analysed strains (i.e., A. niger). The OTA values obtained for each accelerated storage time point are listed in Table 5.

Table 5. Concentrations of ochratoxin A (OTA) determined for 12 Aspergillus strains at different preservation time points (before (Time I), after 2 weeks (Time II) and 4 weeks (Time III) of freeze-drying).

\begin{tabular}{|c|c|c|c|c|}
\hline \multirow{2}{*}{ Species } & \multirow{2}{*}{ Strain MUM No. } & \multicolumn{3}{|c|}{ OTA ng/mL (Rt * = $16.2 \mathrm{~min})$} \\
\hline & & $\mathbf{I}$ & II & III \\
\hline A. aculeatus & 03.11 & - & - & - \\
\hline A. brasiliensis & 06.179 & 1.8 & 17.5 & 26.8 \\
\hline \multirow[t]{3}{*}{ A. ibericus } & 03.49 & - & - & - \\
\hline & 04.68 & - & - & - \\
\hline & 04.86 & - & - & - \\
\hline A. japonicus & 98.03 & - & - & - \\
\hline A. lacticoffeatus & 06.150 & 535.5 & 2.6 & 705.1 \\
\hline \multirow[t]{2}{*}{ A. niger } & 05.11 & 2508.0 & 4858.4 & 2673.1 \\
\hline & 05.13 & - & - & - \\
\hline A. phoenicis & 03.05 & 4.2 & 13.3 & 7.2 \\
\hline A. uvarum & 08.01 & - & - & - \\
\hline A. vadensis & 06.153 & - & 12.3 & 39.0 \\
\hline
\end{tabular}

More than $40 \%$ of the analysed strains are ochratoxigenic, and some changes in OTA production were found between preservation time points. Although those were apparently not associated with preservation and ageing, results showed that OTA production was stimulated in A. brasiliensis MUM 06.179 and A. vadensis MUM 06.153 after accelerated storage.

Changes in mycotoxin production patterns due to preservation techniques were observed in other filamentous fungi [53]. However, other authors have shown that the variability in mycotoxins production seems to be more strain-specific than due to the used preservation technique $[16,53]$. In addition, changes in mycotoxin production patterns have been related to physiological instability in filamentous fungi [54]. Secondary metabolites synthesis is often related to nutrient depletion, abiotic stress, as well as possible ecological roles in nature $[55,56]$.

\subsection{MALDI-TOF MS Spectral Analysis}

When analysing filamentous fungi through MALDI-TOF MS, a signature profile is obtained by pre-processing a raw spectrum and reducing it to a set of $\mathrm{m} / \mathrm{z}$ and relative intensity points that represent the sample proteome in the range from 2 to $20 \mathrm{kDa}[26,28]$. Reproducibility of spectra is not always achieved. In fact, a small percentage of differences can be easily justified by variation in several parameters, from culture conditions or sample preparation, to equipment and laser age $[27,28]$. Furthermore, heterogeneous morphological phenotypes of filamentous fungi can be translated into variable MALDI-TOF mass spectra, either between different strains of the same species as well as between subcultures or distinct tissue samples of the same strain [28,57].

According to Santos et al. [24], fungal identification by MALDI-TOF MS can be impacted by modifications of the protein extraction methodology, and by increasing both the number of reference spectra of a given strain included in the reference library and the number of deposits used to generate each reference spectra. Three recent review works highlight the importance of having a comprehensive and well-curated reference database and how this is still a major limitation for the identification of filamentous fungi using commercially available platforms [26-29]. However, when using a comparison 
of spectra to understand the differences between different time points of a preservation method, as in this particular case, the main focus was to observe the main peaks obtained in each spectra with no need to employ any given comparison database.

In all the analysed strains it was possible to see that, after preservation and ageing, there were differences in the spectral data with an increase in the number of peaks, particularly for time point II, or decrease in the case of time point III (Table 6).

Table 6. Variation in the number of spectral data peaks for time points II and III in comparison with time point I for 12 Aspergillus strains.

\begin{tabular}{ccccc}
\hline \multirow{2}{*}{ Species } & Strain MUM No. & \multicolumn{3}{c}{ No. of Peaks Variation for Time Points } \\
\cline { 3 - 5 } & & I & II & III \\
\hline A. aculeatus & 03.11 & 75 & 59 & 58 \\
\hline A. brasiliensis & 06.179 & 91 & 120 & 119 \\
\hline A. ibericus & 03.49 & 84 & 87 & 58 \\
& 04.68 & 65 & 94 & 37 \\
& 04.86 & 80 & 93 & 48 \\
\hline A. japonicus & 98.03 & 54 & 73 & 53 \\
\hline A. lacticoffeatus & 06.150 & 87 & 94 & 97 \\
\hline A. niger & 05.11 & 56 & 69 & 41 \\
& 05.13 & 79 & 74 & 39 \\
\hline A. phoenicis & 03.05 & 83 & 102 & 66 \\
\hline A. uvarum & 08.01 & 106 & 76 & 39 \\
\hline A. vadensis & 06.153 & 102 & 99 & 105 \\
\hline
\end{tabular}

Such variations were not sufficient to disturb sample grouping in the dendrogram of proteomic profile relatedness presented in Figure 3.

It is possible to observe that 8 out of 12 Aspergillus section Nigri strains formed groups that included the three-time points tested. Furthermore, for the remaining strains considered here, the three-time points are located in close branches. In other words, the preservation and ageing processes did not affect the proteome in the range from 2 to $20 \mathrm{kDa}$ of the majority of samples and consequently did not significantly affect the grouping of MALDI-TOF MS spectra of fungal strains.

It is also worth mentioning that MALDI-TOF MS spectral analysis is capable of grouping strains within the same species (Figure 3). Our results show that $A$. niger and A. ibericus strains form two distinct and well-defined groups. In the case of $A$. niger, our results are in accordance with the recent whole genome based conclusion that $A$. phoenicis is a synonym of A. niger [58], as strain MUM 03.05 forms a group at approximately $40 \%$ relatedness with MUM 05.11 and MUM 05.13. However, from the MALDI-TOF MS data presented here, we are unable to support the same study's affirmation that $A$. lacticoffeatus MUM 06.150 is also an A. niger synonym which can be related with the metabolic mutation at the PKS gene ( $p k s \mathrm{~A})$ for the production of black conidium pigment [59]. 


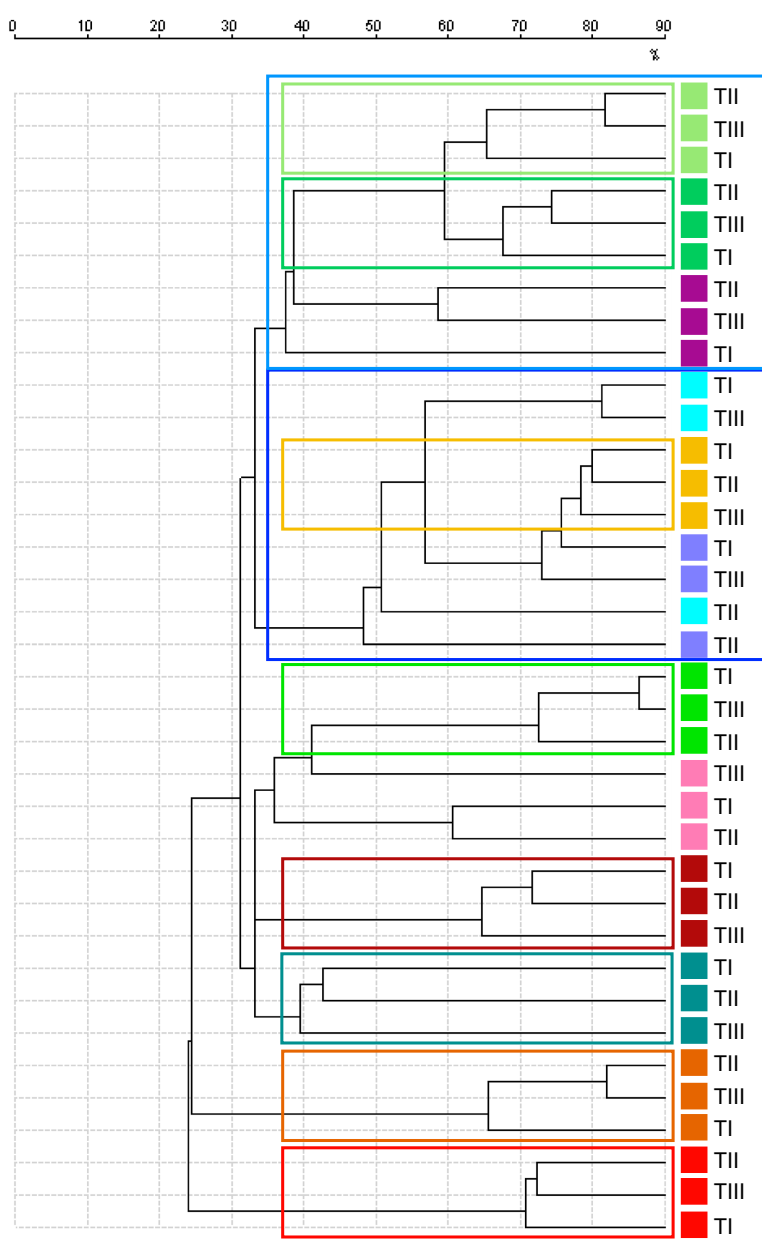

A. nigergroup

A. Ibericus group

Figure 3. Dendrogram of proteomic relatedness with data from three preservation time points. TI-before preservation; TII-2 weeks of accelerated storage; and TIII-4 weeks of accelerated storage.

Coloured boxes indicate strains where the three-time points cluster together.

\subsection{Molecular Biology: Typing Assays}

To identify genetic changes in strains after preservation, amplification of hypervariable inter-repeat DNA fragments using a single primer M13 was performed. The M13 profiles varied between 0.3 and $3.0 \mathrm{~kb}$ with some strains showing a large number of bands with variable degrees of intensity (Figure 4A). This may be related to the number of regions homologous to the specific sequences of M13 dispersed in the genome of each strain $[41,60]$. Seven out of 12 fungal strains presented little differences in their fingerprinting patterns resulting in clustering of the three time points for each sample: $A$. phoenicis MUM 03.05, A. niger MUM 05.11 and MUM 05.13, A. lacticoffeatus MUM 06.150, A. vadensis MUM 06.153, A. brasiliensis MUM 06.179 and A. uvarum MUM 08.01 (Figure 4A). The PCA analysis plotted in Figure 4B allows a better visualisation of these relationships where A. brasiliensis MUM 06.179 shows more dispersion, immediately followed by A. niger MUM 05.11 when compared with the other five strains. It is interesting to note that five of these samples also grouped in the MALDI-TOF MS results. 
(A)

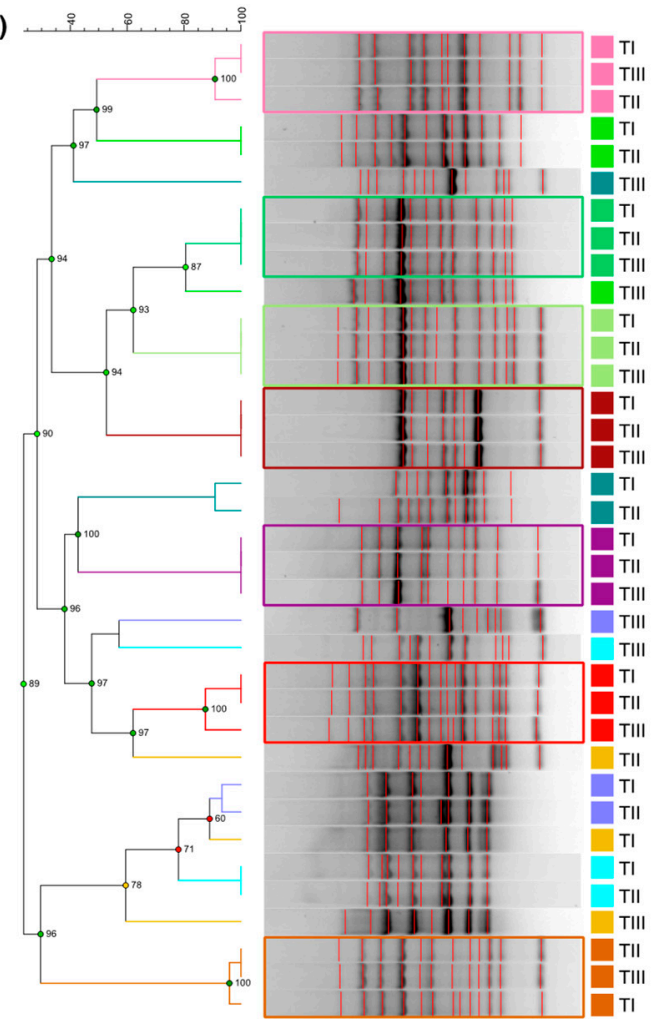

(B)

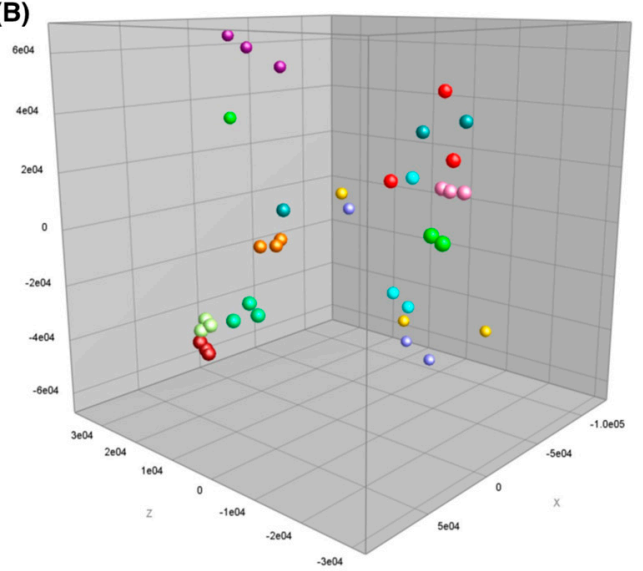

Figure 4. M13 fingerprinting results with data from three preservation time points. TI-before preservation; TII-2 weeks of accelerated storage; and TIII-4 weeks of accelerated storage. (A) dendrogram based on Dice coefficient and UPGMA. Cophenetic correlation coefficient values associated with the branches are shown in the nodes. Coloured boxes indicate strains where the three-time points cluster together. (B) principal component analysis plot.

Recently, a study on Aspergillus section Nigri has shown a high degree of homogeneity of the species pan-genomes [58]. Nevertheless, inter- and intraspecific variation exists and can be explored in studies involving related strains. A commonly used technique is randomly amplified polymorphic DNA (RAPD) fingerprinting. RAPD can generate highly informative data [61] despite the reported low reproducibility and limitations that include a lack of consideration of possible polymorphisms present in the sequence of equally sized bands $[62,63]$. Such limitations probably explain the differences in clustering capacity of same species profiles when compared to MALDI-TOF MS (Figure 3). In fact, M13 fingerprinting results (Figure 4) show very limited clustering capacity of $A$. niger strains. As mentioned above, A. phoenicis is a synonym of A. niger [59], a finding that is only partially supported by our fingerprinting results as the three time points of strain MUM 03.05 cluster with all MUM 05.13 samples. Nevertheless, A. niger MUM 05.11 and A. lacticoffeatus MUM 06.150 (also defined as A. niger synonym by [58]) both cluster in different branches of the dendrogram (Figure 4).

The found genetic polymorphisms can be interpreted as a sign of stress induced by the freeze-drying and ageing processes. These can be related to phenotypical alterations even when the proteome is unaffected as exemplified by A. aculeatus MUM 03.11. This strain's time III fingerprinting profile does not cluster with time I and II and is sectorised after 4 weeks of ageing in all media (Figure 2). Susceptibility to genetic alterations appears to be species-specific-contrary to all A. niger strains (including MUM 03.05 and MUM 06.150), each of the three A. ibericus strains included in this study show differences between preservation time points (Figure 4). Similar results have been reported [16,20], where genetic polymorphisms were observed after preserving fungal strains by the freeze-drying method, demonstrating that it is necessary to perform long-term validation studies of the used preservation methods. 


\section{Conclusions}

In this work, 12 selected Aspergillus section Nigri strains were preserved by freeze-drying and then aged by accelerated storage in the dark at $37^{\circ} \mathrm{C}$ for specific time points. The evaluation of all samples within the several time points was done through a polyphasic characterisation. The methods used showed that with time, the freeze-dried samples suffer changes to variable degrees. Little morphological differences were observed, and those were restricted to sectorisations at macro-morphological level, which can be explained by preservation-induced stress.

Regarding the proteolytic and polysaccharide-hydrolytic enzymes studied here, increased activity was observed, which does not represent a limitation on the strains' biotechnological potential. On the other hand, the preservation and long-term storage of strains can cause physiological instability that affects mycotoxins production. This effect might be species or even strain-dependent as production was either stimulated or decreased. Furthermore, these conclusions are only based on OTA production levels and in a limited set of strains and so other mycotoxins and species should be further studied.

MALDI-TOF MS results showed that, at a proteomic fingerprint level, strains and species are quite stable. As the proteome, in the range of 2 to $20 \mathrm{kDa}$, is mainly completed by the fungal ribosomal proteins' machinery, this technique gives good indications of the low impact that preservation and the long-term store might have on these target proteins. These results also support the idea that MALDI-TOF MS is a valuable tool capable of grouping related samples even when molecular biology tests fail to do so. In addition, and in what M13 fingerprinting is concerned, despite the limitations on the extent of clustering capability of this tool, the observed genetic polymorphisms show some overlap with those of spectral analysis.

In spite of the changes detected using an array of methodologies, we consider that those could not cause major impacts in biotechnologically relevant strains of Aspergillus section Nigri if the features that make them valuable or unique after the freeze-drying persisted intact. For each valuable or unique strain, the freeze-drying long-term preservation needs to be assessed before having full trust in this technique. In case freeze-drying shows a variation in the uniqueness biotechnological feature that undermines the fit-for-propose of the strain other preservation techniques, such as cryopreservation at $-80{ }^{\circ} \mathrm{C}$ or under liquid nitrogen, should be considered.

Author Contributions: All authors contributed to the drafting of this manuscript. Conceptualisation, M.F.S., C.S. (Cledir Santos) and N.L.; investigation, R.R., C.S. (Carla Santos), M.F.S. and C.S. (Célia Soares); writing the first draft, M.F.S., R.R., C.S. (Carla Santos) and C.S. (Célia Soares); all authors edited the manuscript and approved the final draft; funding acquisition, C.S. (Cledir Santos) and N.L.

Funding: This research was funded by the Portuguese Foundation for Science and Technology (FCT) under the scope of the strategic funding of UID/BIO/04469/2019 unit and BioTecNorte operation (NORTE-01-0145-FEDER-000004) funded by the European Regional Development Fund under the scope of Norte2020-Programa Operacional Regional do Norte. Cl.S. (Cledir Santos) thanks the Universidad de La Frontera (Temuco, Chile) for the partial funding from the Project DIUFRO PIA19-0001. R.R. thanks to CONICYT/Chile for the MSc grant Folio $\mathrm{N}^{\circ} 7317076$, Application $\mathrm{N}^{\circ} 73170764$.

Acknowledgments: Authors thank Applied Maths for the BioNumerics evaluation licence ticket \#:049000107, and to Laurence Lesage-Meessen and David Navarro from the International Centre of Microbial Resources dedicated to Filamentous Fungi (CIRM-CF), INRA/French National Institute for Agricultural Research at Marseille, France, where the high throughput screening of fungal enzymes was performed under the Transnational Access Grants within the EMbaRC European Project (FP7-228310). MALDI-TOF MS analyses were partially developed using an equipment funded by CONICYT/Chile through the project Fondequip EQM160054 2016.

Conflicts of Interest: The authors declare no conflict of interest.

\section{References}

1. Simões, M.F.; Pereira, L.; Santos, C.; Lima, N. Polyphasic identification and preservation of fungal diversity: Concepts and applications. In Management of Microbial Resources in the Environment; Malik, A., Grohmann, E., Alves, M., Eds.; Springer: Dordrecht, The Netherlands, 2013; pp. 91-117.

2. Deshmukh, R.; Khardenavis, A.A.; Purohit, H.J. Diverse metabolic capacities of fungi for bioremediation. Indian J. Microbiol. 2016, 56, 247-264. [CrossRef] [PubMed] 
3. Espinel-Ingroff, A.; Montero, D.; Martin-Mazuelos, E. Long-term preservation of fungal isolates in commercially prepared cryogenic microbank vials. J. Clin. Microbiol. 2004, 42, 1257-1259. [CrossRef] [PubMed]

4. Perrone, G.; Gallo, A. Aspergillus species and their associated mycotoxins. In Mycotoxigenic Fungi; Moretti, A., Susca, A., Eds.; Methods in Molecular Biology; Humana Press: New York, NY, USA, 2017; Volume 1542.

5. Gullo, V.P.; Lam, T.Y.K.; Monaghan, R.L. Hypocholesterolemic Fermentation Products and Process of Preparation. United States Patent US4432996A, 4 November 1980.

6. Hong, S.B.; Lee, M.; Kim, D.H.; Varga, J.; Frisvad, J.C.; Perrone, G.; Gomi, K.; Yamada, O.; Machida, M.; Houbraken, J.; et al. Aspergillus luchuensis, an industrially important black Aspergillus in East Asia. PLoS ONE 2013, 8, e63769. [CrossRef]

7. Subhan, M.; Faryal, R.; Macreadie, I. Exploitation of Aspergillus terreus for the production of natural statins. J. Fungi 2016, 2, 13. [CrossRef] [PubMed]

8. Mishra, V.K.; Passari, A.K.; Chandra, P.; Leo, V.V.; Kumar, B.; Uthandi, S.; Thankappan, S.; Gupta, V.K.; Singh, B.P. Determination and production of antimicrobial compounds by Aspergillus clavatonanicus strain MJ31, an endophytic fungus from Mirabilis jalapa L. using UPLC-ESI-MS/MS and TD-GC-MS analysis. PLoS ONE 2017, 12, e0186234. [CrossRef] [PubMed]

9. Banjo, T.; Kareem, S.; Akinduti, P.; Popoola, T.; Akinloye, O. Optimization and production of ascorbic acid by fusant cell of Aspergillus flavus and Aspergillus tamarii. J. King Saud Univ. Sci. 2018. [CrossRef]

10. Maciel, M.; Ottoni, C.; Santos, C.; Lima, N.; Moreira, K.; Souza-Motta, C. Production of polygalacturonases by Aspergillus section Nigri strains in a fixed bed reactor. Molecules 2013, 18, 1660-1671. [CrossRef]

11. Barbesgaard, P.; Heldt-Hansen, H.P.; Diderichsen, B. On the safety of Aspergillus oryzae: A review. Appl. Microbiol. Biotechnol. 1992, 36, 569-572. [CrossRef]

12. Rodrigues, P.; Venâncio, A.; Kozakiewicz, Z.; Lima, N. A polyphasic approach to the identification of aflatoxigenic and non-aflatoxigenic strains of Aspergillus section Flavi isolated from Portuguese almonds. Int. J. Food Microbiol. 2009, 129, 187-193. [CrossRef]

13. Paterson, R.R.M.; Lima, N. Toxicology of mycotoxins. In Molecular, Clinical and Environmental Toxicology. Experientia Supplementum; Luch, A., Ed.; Birkhäuser: Basel, Switzerland, 2010; Volume 100, pp. 31-63.

14. Da Silva, F.C.; Chalfoun, S.M.; Batista, L.R.; Santos, C.; Lima, N. Use of a polyphasic approach including MALDI-TOF MS for identification of Aspergillus section Flavi strains isolated from food commodities in Brazil. Ann. Microbiol. 2015, 65, 2119-2129. [CrossRef]

15. Baker, M.; Jeffries, P. Use of commercially available cryogenic vials for long-term preservation of dermatophyte fungi. J. Clin. Microbiol. 2006, 44, 617-618. [CrossRef] [PubMed]

16. Ryan, M.J.; Jeffries, P.; Bridge, P.D.; Smith, D. Developing cryopreservation protocols to secure fungal gene function. Cryo Lett. 2001, 22, 115-124.

17. Homolka, L. Methods of cryopreservation in fungi. In Laboratory Protocols in Fungal Biology; Gupta, V., Tuohy, M., Ayyachamy, M., Turner, K., O’Donovan, A., Eds.; Springer: New York, NY, USA, 2012; pp. 9-16.

18. Ryan, M.J.; Smith, D.; Jeffries, P. A decision-based key to determine the most appropriate protocol for the preservation of fungi. World J. Microbiol. Biotechnol. 2000, 16, 183-186. [CrossRef]

19. Karabıçak, N.; Karatuna, O.; Akyar, I. Evaluation of the viabilities and stabilities of pathogenic mold and yeast species using three different preservation methods over a 12-year period along with a review of published reports. Mycopathologia 2016, 181, 415-424. [CrossRef] [PubMed]

20. Voyron, S.; Roussel, S.; Munaut, F.; Varese, G.C.; Ginepro, M.; Declerck, S.; Filipello Marchisio, V. Vitality and genetic fidelity of white-rot fungi mycelia following different methods of preservation. Mycol. Res. 2009, 113, 1027-1038. [CrossRef] [PubMed]

21. Chang, S.; Carneiro-Leão, M.P.; de Oliveira, B.F.; Souza-Motta, C.; Lima, N.; Santos, C.; de Oliveira, N.T. Polyphasic approach including MALDI-TOF MS/MS analysis for identification and characterisation of Fusarium verticillioides in Brazilian corn kernels. Toxins 2016, 8, 54. [CrossRef] [PubMed]

22. Santos, C.; Paterson, R.R.M.; Venâncio, A.; Lima, N. Filamentous fungal characterizations by matrix-assisted laser desorption/ionization time-of-flight mass spectrometry. J. Appl. Microbiol. 2010, 108, 375-385. [CrossRef] [PubMed]

23. Rodrigues, P.; Santos, C.; Venâncio, A.; Lima, N. Species identification of Aspergillus section Flavi isolates from Portuguese almonds using phenotypic, including MALDI-TOF ICMS, and molecular approaches. J. Appl. Microbiol. 2011, 111, 877-892. [CrossRef] [PubMed] 
24. Santos, C.E.; Mazza, M.; Padovan, A.C.B.; Paterson, R.R.M.; Colombo, A.; Lima, N. Barriers and advances in mycology: Impact of MALDI-TOF in clinical diagnostics. In MALDI-TOF and Tandem MS for Clinical Microbiology; Shah, H.N., Gharbia, S.E., Eds.; Wiley: Chichester, UK, 2016; Chapter 9; pp. 211-230.

25. Santos, C.; Ventura, J.A.; Lima, N. New insights for diagnosis of pineapple fusariosis by MALDI-TOF MS technique. Curr. Microbiol. 2016, 73, 206-213. [CrossRef]

26. Cassagne, C.; Normand, A.C.; L'Ollivier, C.; Ranque, S.; Piarroux, R. Performance of MALDI-TOF MS platforms for fungal identification. Mycoses 2016, 55, 678-690. [CrossRef]

27. Sanguinetti, M.; Posteraro, B. Identification of molds by matrix-assisted laser desorption ionization-time of flight mass spectrometry. J. Clin. Microbiol. 2017, 55, 369-379. [CrossRef] [PubMed]

28. Patel, R. A moldy application of MALDI: MALDI-TOF Mass Spectrometry for fungal identification. J. Fungi 2019, 5, 4. [CrossRef] [PubMed]

29. Sakane, T.; Kuroshima, J. Viabilities of dried cultures of various bacteria after preservation for over 20 years and their prediction by the accelerated storage test. Microbiol. Cult. Coll. 1997, 13, 1-7.

30. Yordanova, A.; Stoimenova, E.; Donev, T. Application of accelerated storage test to lyophilized plant viruses. Biotechnol. Tech. 1996, 10, 977-982. [CrossRef]

31. Ellis, J.J.; Roberson, J.A. Viability of fungus cultures preserved by lyophilisation. Mycologia 1968, 60, $399-405$.

32. McGinnis, M.R.; Padhye, A.A.; Ajello, L. Storage of stock cultures of filamentous fungi, yeasts, and some aerobic Actinomycetes in sterile distilled water. Appl. Microbiol. 1974, 28, 218-222.

33. Qiangqiang, Z.; Jiajun, W.; Li, L. Storage of fungi using sterile distilled water or lyophilisation: Comparison after 12 years. Mycoses 1998, 41, 255-257. [CrossRef]

34. Guimarães, L.C.; Fernandes, A.P.; Chalfoun, S.M.; Batista, L.R. Methods to preserve potentially toxigenic fungi. Braz. J. Microbiol. 2014, 45, 43-47. [CrossRef]

35. Paul, J.S.; Tiwari, K.L.; Jadhav, S.K. Long term preservation of commercial important fungi in glycerol at $4{ }^{\circ} \mathrm{C}$. Int. J. Biol. Chem. 2015, 9, 79-85.

36. Navarro, D.; Couturier, M.; da Silva, G.G.D.; Berrin, J.G.; Rouau, X.; Asther, M.; Bignon, C. Automated assay for screening the enzymatic release of reducing sugars from micronized biomass. Microb. Cell Fact. 2010, 9 , 1-11. [CrossRef]

37. Gonçalves, C.; Rodriguez-Jasso, R.M.; Gomes, N.; Teixeira, J.A.; Belo, I. Adaptation of dinitrosalicylic acid method to microtiter plates. Anal. Methods 2010, 2, 2046-2048. [CrossRef]

38. Bradford, M.M. A rapid and sensitive method for the quantitation of microgram quantities of protein utilizing the principle of protein-dye binding. Anal. Biochem. 1976, 72, 248-254. [CrossRef]

39. Bragulat, M.R.; Abarca, M.L.; Cabañes, F.J. An easy screening method for fungi producing ochratoxin A in pure culture. Int. J. Food Microbiol. 2001, 71, 139-144. [CrossRef]

40. Abrunhosa, L.; Calado, T.; Resende, T.; Venâncio, A. A fluorescence-LC method with NDA pre-column derivatization for fumonisin B2 determination in black aspergilli cultures. J. Liq. Chromatogr. Relat. Technol. 2011, 34, 1594-1603. [CrossRef]

41. Huey, B.; Hall, J. Hypervariable DNA fingerprinting in Escherichia coli: Minisatellite probe from bacteriophage M13. J. Bacteriol. 1989, 171, 2528-2532. [CrossRef]

42. Seidel-Rogol, B.L.; King, J.; Bertrand, H. Unstable mitochondrial DNA in natural-death nuclear mutants of Neurospora crassa. Mol. Cell Biol. 1989, 9, 4259-4264. [CrossRef] [PubMed]

43. Ryan, M.J.; Bridge, P.D.; Smith, D.; Jeffries, P. Phenotypic degeneration occurs during sector formation in Metarhizium anisopliae. J. Appl. Microbiol. 2002, 93, 163-168. [CrossRef]

44. Wang, C.; Butt, T.M.; St Leger, R.J. Colony sectorization of Metarhizium anisopliae is a sign of ageing. Microbiology 2005, 151, 3223-3236. [CrossRef]

45. Li, L.; Hu, X.; Xia, Y.; Xiao, Y.; Zheng, P.; Wang, C. Linkage of oxidative stress and mitochondrial dysfunctions to spontaneous culture degeneration in Aspergillus nidulans. Mol. Cell Proteom. 2014, 13, 449-461. [CrossRef]

46. Klich, M.A. Identification of Common Aspergillus Species; Centraalbureau voor Schimmelautures: Utrecht, The Netherlands, 2002.

47. Simões, M.F.; Santos, C.; Lima, N. Structural diversity of Aspergillus (Section Nigri) spores. Microsc Microanal. 2013, 19, 1151-1158. [CrossRef]

48. Abdallah, M.F.; Krska, R.; Sulyok, M. Occurrence of ochratoxins, fumonisin B2, aflatoxins (B1 and B2), and other secondary fungal metabolites in dried date palm fruits from Egypt: A mini-survey. J. Food Sci. 2018, 83, 559-564. [CrossRef] [PubMed] 
49. Kozakiewicz, Z. Aspergillus Species on Stored Products; C.A.B. International: Wallingford, UK, 1989; pp. 1-188.

50. Serra, R.; Abrunhosa, L.; Kozakiewicz, Z.; Venâncio, A. Black Aspergillus species as ochratoxin A producers in Portuguese wine grapes. Int. J. Food Microbiol. 2003, 88, 63-68. [CrossRef]

51. Astoreca, A.L.; Magnoli, C.E.; Dalcero, A.M. Ecophysiology of Aspergillus section Nigri species potential ochratoxin A producers. Toxins 2010, 2, 2593-2605. [CrossRef] [PubMed]

52. Storari, M.; Dennert, F.G.; Bigler, L.; Gessler, C.; Broggini, G.A.L. Isolation of mycotoxins producing black aspergilli in herbal teas available on the Swiss market. Food Control 2012, 26, 157-161. [CrossRef]

53. Santos, I.M.; Abrunhosa, L.; Venâncio, A.; Lima, N. The effect of culture preservation techniques on patulin and citrinin production by Penicillium expansum Link. Lett. Appl. Microbiol. 2002, 35, 272-275. [CrossRef] [PubMed]

54. Shuba, K.; Bennet, J.W. Strain instability in filamentous fungi. In Handbook of Applied Mycology: Mycotoxins in Ecological Systems; Bhatnagar, D., Lillehoj, E.B., Arora, D.K., Eds.; Marcel Dekker: New York, NY, USA, 1992; Volume 5, pp. 311-331.

55. Calvo, A.M.; Wilson, R.A.; Bok, J.W.; Keller, N.P. Relationship between secondary metabolism and fungal development. Microbiol. Mol. Biol. Rev. 2002, 66, 447-459. [CrossRef] [PubMed]

56. Betina, V. Mycotoxins-Chemical, biological and environmental aspects. Bioactive Molecules. 1989, 9, $27-41$.

57. Normand, A.C.; Cassagne, C.; Ranque, S.; L'Ollivier, C.; Fourquet, P.; Roesems, S.; Hendrickx, M.; Piarroux, R. Assessment of various parameters to improve MALDI-TOF MS reference spectra libraries constructed for the routine identification of filamentous fungi. BMC Microbiol. 2013, 13, 76. [CrossRef]

58. Vesth, T.C.; Nybo, J.L.; Theobald, S.; Frisvad, J.C.; Larsen, T.O.; Nielsen, K.F.; Hoof, J.B.; Brandl, J.; Salamov, A.; Riley, R.; et al. Investigation of inter- and intraspecies variation through genome sequencing of Aspergillus section Nigri. Nat. Genet. 2018, 50, 1688-1695. [CrossRef]

59. Jørgensen, T.R.; Park, J.; Arentshorst, M.; van Welzen, A.M.; Lamers, G.; Vankuyk, P.A.; Damveld, R.A.; van den Hondel, C.A.M.; Nielsen, K.F.; Frisvad, J.C.; et al. The molecular and genetic basis of conidial pigmentation in Aspergillus niger. Fungal Genet. Biol. 2011, 48, 544-553. [CrossRef]

60. Meyer, W.; Mitchell, T.G. Polymerase chain reaction fingerprinting in fungi using single primers specific to minisatellites and simple repetitive DNA sequences: Strain variation in Cryptococcus neoformans. Electrophoresis 1995, 16, 1648-1656. [CrossRef]

61. Pujol, C.; Joly, S.; Lockhart, S.R.; Noel, S.; Tibayrenc, M.; Soll, D.R. Parity among randomly amplified polymorphic DNA method, multilocus enzyme electrophoresis, and southern blot hybridization with the moderately repetitive DNA probe Ca3 for fingerprinting of Candida albicans. J. Clin. Microbiol. 1997, 35, 2348-2358. [PubMed]

62. Gil-Lamaignere, C.; Roilides, E.; Hacker, J.; Müller, F.-M.C. Molecular typing for fungi-A critical review of the possibilities and limitations of currently and future methods. Clin. Microbiol. Infect. 2003, 9, 172-185. [CrossRef] [PubMed]

63. Soll, D.R. The ins and outs of DNA fingerprinting the infectious fungi. Clin. Microbiol. Rev. 2000, 13, 332-370. [CrossRef] [PubMed]

(C) 2019 by the authors. Licensee MDPI, Basel, Switzerland. This article is an open access article distributed under the terms and conditions of the Creative Commons Attribution (CC BY) license (http://creativecommons.org/licenses/by/4.0/). 